\section{MIDLAND ORNITHOLOGY}

Atlas of Breeding Birds of the West Midlands

Edited by J. Lord and D. J. Munns. Pp. 276. (Collins: London, March 1970. Published for the West Midland Bird Club.) $30 s$.

THE large-scale mapping of plant and animal distributions is really a comparatively recent development. Such mapping has been undertaken in the past for certain rare and/or local species; but now moves are afoot to map all species in most classes at a national level. The movement really began with the well known work of the Botanical Society of the British Isles, whose Atlas of the British Flora was published in 1962. This botanical atlas was based on presence or absence of species in 10 kilometre squares of the National Grid, whose concept has now been adopted generally. Much of the credit for this standardization is due to the Biological Records Centre of the Nature Conservancy.

One project now well advanced is that of the British Trust for Ornithology to map bird distributions over Britain and Ireland. This project is now in its third year of a planned five years of field work and good progress is being made, thanks to the efforts of large numbers of ornithologists and bird watchers, most of them amateurs.

Accurate knowledge of bird distribution is valuable locally as well as nationally, and at the regional level the West Midland Bird Club has been especially active. In 1950 it pioneered a breeding bird survey of Staffordshire, Warwickshire and Worcestershire, based on vicecountics; and with these data, as well as more recent work in preparation for the British Trust for Ornithology's scheme, the broad outlines of bird distributions in these three Midland counties have been worked out and are published in this new volume, Atlas of Breeding Birds of the West Midlands. Let it be said at once that this is an admirable volume, a credit to all concerned, and a model for others. The plan is simple. Each species is given a twopage spread, with a distributional map on the left and with interpretative remarks opposite. The maps are the raison d'être, of course. These are gridded into 10 kilometre squares, and the editors give their reasons for not using smaller units ("tetrads", or $2 \mathrm{~km}$ squares, have been used in some local mappings elsewhere). Map entries are on a presence or absence basis, and three symbols are used to denote (i) presence in summer without evidence of nesting; (ii) probable breeding; and (iii) confirmed breeding. My only criticism concerns the lack of a detailed geological map, which would have helped interpretation by those unfamiliar with the area.

This book is a must for the libraries of all Midlands ornithologists, and may be perused with profit by any naturalist contemplating mapping projects of his chosen group.

ROBERT HUDSON

\section{NON-CELLULAR SLIME MOULDS}

\section{The Myxomycetes}

By G. W. Martin and C. J. Alexopoulos. Pp. ix $+561+$ 41 plates. (University of Towa Press: Iowa City, 1969.) $\$ 30$.

The past decade has been one of unprecedented activity in the study of Myxomycetes, otherwise known as the Mycetozoa or non-cellular slime moulds. Yet the last world-wide treatment of the group, Lister's monograph, is nearly half a century old and for identification workers have been obliged to resort to regional studies, such as Martin's own 1949 monograph of North American species. The appearance of a new monograph listing all species described up to 1967 is therefore welcome. It is particularly fortunate that such a monograph should result from the collaboration of G. W. Martin, perhaps the world's most experienced myxomycete taxonomist, and C. J.
Alexopoulos, an authority on the laboratory culture of Myxomycetes who has initiated an experimental approach to the taxonomy of the group.

A short introduction includes sections on the collection and care of the fruiting bodies on which identification is based and on the taxonomic history of Myxomycetes. The greater part of the book consists of descriptions of the several hundred known species based largely on specimens in the great Macbride-Martin collection of the University of Iowa, but supplemented where necessary by the study of material from other herbaria, and of dichotomous keys to facilitato their identification. The descriptions and accompanying literature citations and lists of synonyms are detailed and scholarly, and the keys, as far as I am able to judge from limited tests, easy to use. The nomenclature and classification used are, as the authors concede, conservative. Their restraint in this is to be commended, because radical revision of myxomycete classification should be deferred until a great deal more is known about laboratory culture, fruiting body development, cytology and physiology. An appendix lists and discusses specific names of doubtful meaning and validity but encountered by the authors in the literature. The book ends with 41 colour plates illustrating 367 species. Having compared freshly collected fruiting bodies with the corresponding illustrations in this and other volumes, I suspect that students, having identified their specimens from the present text, will still turn to the magnificent illustrations of Lister's 1925 monograph or Hattori's Myxomycetes of the Nasu District for eonfirmation. Perhaps a judicious selection of photographs, line drawings and a few colour plates illustrating a smaller number of species would have been a happier approach, although I concede that authors, artist, printers and publisher had an exceptionally difficult problem to face.

The volume is of robust construction, an admirable feature in one intended for the laboratory as well as the study. Martin and Alexopoulos have produced a work of great scholarship, one that is likely to be the standard work on the group for many years, and to be essential wherever serious study of Myxomycetes is undertaken.

\section{J. CARLILE}

\section{PERIOD PIECE REVISED}

\section{Oncogenic Viruses}

By Ludwik Gross. Second edition, completely revised and enlarged. Pp. xxii +991 . (Pergamon: Oxford, London and New York, May 1970.) 250s; \$32.

Thrs new edition of Dr Ludwik Gross's book retaius all the idiosyncrasies of the first edition published in 1961. It is the book of a man whose approach to tumour virology has changed little since the late forties and early fiftiesa period when Gross was making his outstanding contributions to the subject with his work on viral leukaemias and the discovery of polyoma virus. As a result Oncogenic Viruses provides an interesting insight into the way of thinking of tumour virologists before the WatsonCrick era. Both the great length and the historical style of the book testify to the more leisurely pace of science during the author's formative years.

Obviously this is not a book to recommend to anybody fresh to the subject and set on learning why tumour virology is currently so exciting. There is no mention whatsoever of the way in which both the methods and the concepts of molecular biology, gained during the past decade from work with bacteria and their phages, have changed the face of tumour virology. For example, in his revised chapter on polyoma virus, which covers no less than 101 pages, Gross fails to find space even to touch on the idea that the small DNA tumour viruses may transform cells by a process analogous to bacterial lysogeny. On the other hand, he describes an almost daily chronology 